\title{
Korelasi Nilai Mean Platelet Volume dengan Derajat Fibrosis Hati pada Pasien Hepatitis B Kronik
}

\author{
Sri Wayati Yuza1 ${ }^{1}$ Ellyza Nasrul², Efrida²
}

\begin{abstract}
Abstrak
Biopsi hati merupakan baku emas penentuan derajat fibrosis hati, tetapi bersifat invasif. Metode non invasif yang dikembangkan saat ini untuk mengetahui derajat fibrosis hati adalah fibroscan, tetapi tidak tersedia di semua fasilitas kesehatan. Nilai Mean Platelet Volume (MPV) yang terdapat dalam pemeriksaan darah rutin dapat dijadikan penanda keparahan fibrosis hati pada pasien hepatitis B kronik. Tujuan: Menilai korelasi nilai MPV dan derajat fibrosis hati pada pasien hepatitis B kronik. Metode: Penelitian ini adalah suatu penelitian analitik dengan rancangan potong lintang terhadap 25 orang pasien hepatitis B kronik yang memenuhi kriteria inklusi dan eksklusi. Pasien melakukan pemeriksaan darah rutin dan fibroscan di RSUP Dr. M. Djamil Padang pada bulan April sampai Agustus 2019. Pemeriksaan nilai MPV menggunakan alat analisis hematologi otomatis metode impedensi. Data dianalisis dengan uji korelasi Pearson. Penelitian dilakukan pada 25 orang pasien hepatitis B kronik, terdiri dari 13 orang laki-laki dan 12 orang perempuan. Hasil: Rerata umur adalah $44 \pm 11,3$ tahun. Rerata nilai MPV adalah 9,9 $\pm 0,94 \mathrm{fL}$. Rerata derajat fibrosis hati adalah $14 \pm 9,6 \mathrm{kPa}$ (F4). Uji korelasi Pearson menunjukkan korelasi positif lemah antara nilai MPV dan derajat fibrosis hati $(r=0,28)$ tetapi tidak bermakna secara statistik $(p=0,18)$. Simpulan: Terdapat korelasi positif lemah antara nilai MPV dengan derajat fibrosis hati pada pasien hepatitis $B$ kronik.
\end{abstract}

Kata kunci: derajat fibrosis hati, hepatitis B kronik, mean platelet volume

\section{Abstract}

Liver biopsy is the gold standard for determining the liver fibrosis grade, but it is invasive. The non-invasive method currently developed to determine the liver fibrosis grade is fibroscan, but it is not available in all of healthy center. Mean Platelet Volume (MPV) values which is contained in routine blood tests can be used as a marker of the severity of liver fibrosis in patients with chronic hepatitis $B$, because it is a marker of liver inflammation. Objectives:To asses MPV value correlation with liver fibrosis grade in chonic hepatitis B patients. Methods: This research was an analytic study with a cross-sectional design of 25 chronic hepatitis $B$ patients who met the inclusion and exclusion criteria. Patients undergone routine blood and fibroscan examinations at Central of General Hospital Dr. M. Djamil Padang from April to August 2019. The determination of MPV levels used an automatic hematology analyzer with the impedance method. The data were analyzed by Pearson's correlation test. The study was conducted on 25 patients with chronic hepatitis $B$, consist of 13 males and 12 females. Results: The mean age was $44 \pm 11$. years old. The mean of MPV value was $9.9 \pm 0.94 \mathrm{fL}$. The mean of liver fibrosis grade was $14 \pm 9.6 \mathrm{kPa}$ (F4). The Pearson comparison test showed a weak positive correlation between the MPV value and liver fibrosis grade $(r=0.28)$, but it didn't show the significant correlation $(p=0,18)$. Conclusion: There is weak positive correlation between MPV value and liver fibrosis grade in chronic hepatitis $B$ patients.

Keywords: liver fibrosis grade, chronic hepatitis $B$, mean platelet volume.

Affiliasi penulis: ${ }^{1}$ Program Pendidikan Dokter Spesialis Patologi Klinik, Fakultas Kedokteran, Universitas Andalas, Padang. ${ }^{2}$ Bagian Patologi Klinik, Fakultas Kedokteran, Universitas Andalas, Padang Korespondensi: sri_wayati84@yahoo.com/ telp 085265554984

\section{PENDAHULUAN}

Hepatitis B kronik adalah peradangan hati kronik akibat virus hepatitis $B(\mathrm{VHB})$ yang berlangsung lebih dari enam bulan, ditandai dengan $\mathrm{HBsAg}$ positif. ${ }^{1,2}$ 
Hepatitis B kronik di Asia Tenggara ditemukan pada sekitar 100 juta orang. Infeksi sebagian besar terjadi pada masa perinatal, umumnya tidak mengalami keluhan atau gejala, sampai terjadi penyakit hati kronik. $^{3}$ Data Riset Kesehatan Dasar yang dikutip Muljono (2017) dari 33 provinsi di Indonesia menunjukkan terjadinya penurunan prevalensi HBsAg positif dari tahun 2007 sampai 2013, yaitu dari 9,4\% menjadi $7,1 \% .{ }^{4}$

Hepatitis B kronik merupakan nekroinflamasi hati yang berlanjut lebih dari 6 bulan, melibatkan proses destruksi yang progresif dan regenerasi parenkim hati hingga terjadi proses fibrosis. Penentuan derajat fibrosis hati sangat membantu klinisi untuk mendapatkan gambaran perjalanan penyakit serta pemberian pengobatan secara dini dan akurat. ${ }^{5}$ Derajat fibrosis hati dapat dinilai dengan beberapa metode. Biopsi hati merupakan baku emas, tetapi bersifat invasif dan memiliki beberapa kelemahan seperti nyeri, perdarahan, dan tergantung pada ketepatan lokasi pengambilan jaringan. Fibroscan merupakan tindakan noninvasif yang banyak dikembangkan di rumah sakit rujukan untuk menentukan derajat fibrosis hati karena bersifat noninvasif, cepat, tanpa nyeri, dan hasil yang cukup akurat karena memiliki sensitivitas dan spesifisitas yang baik, yaitu $70 \%$ dan $83 \% .^{6}$

Mean platelet volume (MPV) merupakan parameter yang terdapat dalam pemeriksaan darah rutin menggunakan alat analisis hematologi otomatis. Nilai MPV mengindikasikan rata-rata ukuran trombosit yang berada dalam sirkulasi, sehingga menggambarkan keadaan stimulasi dan produksi trombosit. Nilai MPV dapat juga dijadikan penanda keparahan fibrosis hati pada pasien hepatitis B kronik, karena peningkatan MPV merupakan penanda adanya inflamasi. $^{7,8}$ Nilai normal MPV adalah 8-10 fL menggunakan alat analasis hematologi otomatis metode impedensi. ${ }^{9}$

Penelitian Ekiz et al tahun 2011 pada 59 pasien hepatitis B kronik dan 25 orang kontrol sehat, mendapatkan peningkatan MPV yang berhubungan dengan derajat fibrosis hati. Penelitian tersebut menyebutkan bahwa MPV dapat digunakan sebagai prediktor independen dalam menentukan derajat fibrosis hati pada pasien hepatitis $\mathrm{B}$ kronik $^{10}$. Rodak et al pada tahun 2018 di Polandia juga menemukan korelasi yang positif $(r=0,79, p=0,001)$ antara MPV dengan keparahan penyakit hepatitis $B$ kronik yang dievaluasi menggunakan transient elastography (Fibroscan) ${ }^{11}$.

Penelitian kohort retrospektif di China oleh Pan et al tahun 2016 pada 677 pasien hepatitis B kronik yang telah melakukan biopsi hati, mendapatkan tidak ada hubungan antara derajat fibrosis hati dengan nilai MPV12. Penelitian Kiratli \& Cevik, tahun 2017 pada 259 pasien hepatitis B kronik yang diteliti secara retrospektif juga tidak menemukan peningkatan nilai MPV ${ }^{7}$.

Berdasarkan latar belakang diatas, maka penulis tertarik untuk meneliti korelasi nilai mean platelet volume dengan derajat fibrosis hati pada pasien hepatitis B kronik di RSUP. Dr. M. Djamil Padang.

\section{METODE}

Penelitian ini adalah suatu STUDI analitik dengan rancangan potong lintang terhadap 25 orang pasien hepatitis B kronik yang melakukan pemeriksaan hematologi rutin di Laboratorium Sentral dan pemeriksaan Fibroscan di Instalasi Diagnostik Terpadu (IDT) RSUP Dr. M. Djamil Padang pada bulan April sampai dengan Agustus 2019. Kriteria inklusi yaitu pasien yang telah didiagnosis hepatitis $B$ kronik oleh klinisi dan berusia 18 - 65 tahun. Kriteria eksklusi adalah kelainan jantung, gagal ginjal, hipertensi, DM, SKA, infeksi kronik, keganasan, penyakit autoimun, kelainan hematologi (ITP, anemia aplasia), dan PPOK, yang diperoleh dari data catatan rekam medis pasien. Pemeriksaan nilai MPV menggunakan alat analisis hematologi otomatis metode impedensi.

\section{Analisis Statistik}

Data univariat ditampilkan dalam bentuk tabel distribusi frekuensi dan diagram. Data bivariat dianalisis dengan metode uji korelasi Pearson jika distribusi normal dan uji korelasi Spearman jika distribusi data tidak normal. Data dianalisis menggunakan program komputer. 


\section{HASIL}

Subjek penelitian terdiri dari 25 orang pasien hepatitis B kronik, terdiri dari 13 orang laki-laki (52\%) dan 12 orang perempuan (48\%). Rerata umur subjek penelitian adalah $44(11,3)$ tahun, seperti yang dapat dilihat pada Tabel 1.

Tabel 1. Karakteristik dasar subjek penelitian

\begin{tabular}{lll}
\hline Variabel & $\mathbf{n}(\%)$ & Rerata (SD) \\
\hline Jenis Kelamin & & \\
Laki-laki & $13(52)$ & \\
Perempuan & $12(48)$ & $44(11,3)$ \\
Umur & & 4 \\
\hline
\end{tabular}

Rerata pemerikssaan MPV adalah 9,9 $(0,9) \mathrm{fL}$. Nilai tertinggi adalah $12,1 \mathrm{fL}$ dan nilai terendah adalah $8,5 \mathrm{fL}$. Hasil pemeriksaan fibroscan didapatkan rarata derajat fibrosis hati $14,04(9,6) \mathrm{kPa}(\mathrm{F} 4)$. Nilai tertinggi adalah $42,5 \mathrm{kPa}$ dan nilai terendah adalah 4,2 kPa.

Tabel 2. Nilai MPV dan derajat fibrosis hati

\begin{tabular}{crl}
\hline \multicolumn{1}{c}{ Variabel } & $\mathbf{n ( \% )}$ & \multicolumn{1}{c}{ Rerata (SD) } \\
\hline Nilai MPV (fL) & & $9,9(0,9)$ \\
Derajat fibrosis (kPa) & & $14,04(9,6)$ \\
F0 & $2(8 \%)$ & \\
F1 & $6(24 \%)$ & \\
F2 & $5(20 \%)$ & \\
F3 & $4(16 \%)$ & \\
F4 & $8(32 \%)$ & \\
\hline
\end{tabular}

Uji normalitas menggunakan Shapiro-Wilk dilakukan terhadap derajat fibrosis hati. Uji ini mendapatkan hasil data tidak terdistribusi normal pada data derajat fibrosis, kemudian dilakukan transformasi log untuk derajat fibrosis hati. Uji korelasi antara nilai MPV dengan derajat fibrosis hati selanjutnya dilakukan dengan uji korelasi Pearson setelah data terdistribusi normal, didapatkan nilai $r=0,28$ dan nilai $p=0,18$.

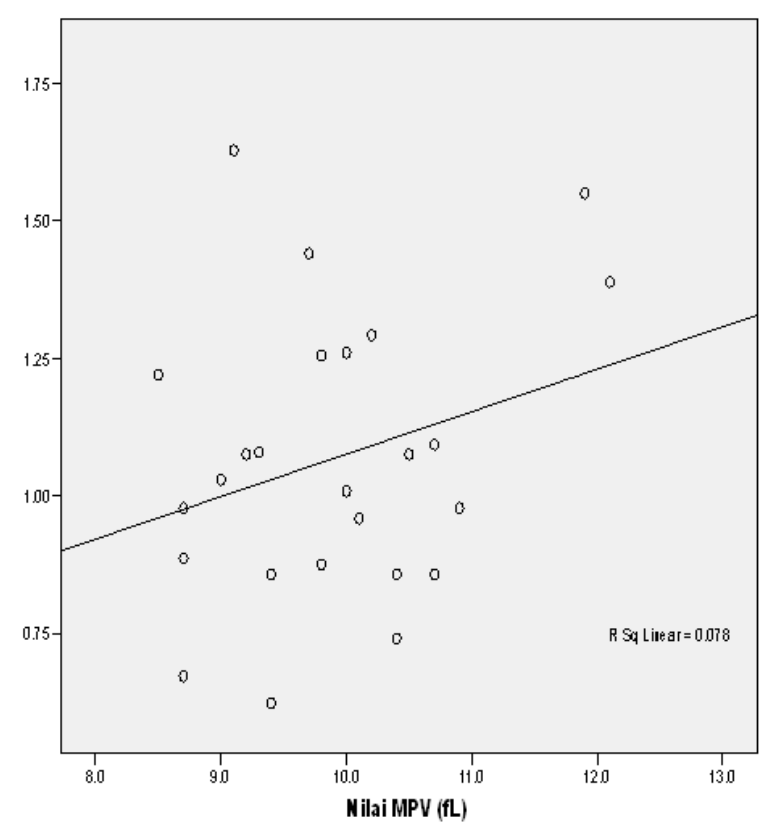

Gambar 1. Kurva linier nilai MPV dengan derajat fibrosis hati

Berdasarkan uji korelasi didapatkan korelasi posititf lemah, tetapi tidak ada hubungan antara nilai MPV dengan derajat fibrosis hati $(r=0,28)$. Korelasi ini tidak bermakna secara statistik $(p>0,05)$.

\section{PEMBAHASAN}

Subjek penelitian adalah 25 orang pasien hepatitis B kronik dengan jenis kelamin laki-laki lebih banyak (52\%) dibandingkan perempuan (48\%). Soeliauwan et al di Makasar pada tahun 2018 meneliti indeks trombosit pada 100 orang pasien hepatitis $B$ kronik, juga mendapatkan pasien laki-laki lebih banyak (56\%) dibandingkan perempuan (44\%). ${ }^{13}$ Ceylan et al tahun 2013 melakukan penelitian indeks trombosit pada 111 pasien hepatitis B kronik, juga mendapatkan pasien laki-laki $(66,7 \%)$ lebih banyak dibandingkan perempuan $(34,3 \%){ }^{14}$ 
Rerata umur subjek penelitian adalah $44 \pm 11,3$ tahun. Hasil tersebut hampir sama dengan beberapa penelitian sebelumnya pada pasien hepatitis B kronik. Penelitian Soeliauwan et al (2018) mendapatkan kejadian hepatitis $B$ kronik terbanyak pada umur 30-49 tahun $^{13}$. Insidens kejadian hepatitis $B$ yang tinggi pada umur 40-49 tahun juga didapatkan pada penelitian Wahyuni tahun 20165. Ekiz et al (2011) juga mendapatkan rerata umur $42,93 \pm 11,5$ tahun. ${ }^{10}$ Kisaran umur tersebut merupakan usia produktif, sehingga risiko terpapar faktor penyebab hepatitis $B$ menjadi lebih tiinggi. ${ }^{5}$

Pemeriksaan nilai MPV didapatkan rerata \pm SD 9,9 $\pm 0,9 \mathrm{fL}$, dengan nilai terendah $8,5 \mathrm{fL}$ dan nilai tertinggi $12,1 \mathrm{fL}$. Hasil penelitian ini hampir sama dengan penelitian Ekiz et al tahun 2011 yang mendapatkan rerata nilai MPV 8,49 $\pm 0,84 \mathrm{fL}$ pada 59 pasien hepatitis $\mathrm{B} \mathrm{kronik}^{10}$. Rerata nilai MPV sebesar $9,2(1,6) \mathrm{fL}$ didapatkan oleh penelitian retrospektif Erdem et al (2018) pada 51 pasien hepatitis B di Turki. Nilai MPV yang didapatkan pada penelitian tersebut lebih tinggi dibandingkan kelompok kontrol sehat yaitu 8,1 (1) fL. ${ }^{15}$ Penelitian Soeliauwan et al (2018) membandingkan nilai MPV pada empat kelompok derajat fibrosis (normal $<5 \mathrm{kPa}$, ringan $=5-9 \mathrm{kPa}$, sedang $=9,1-14,5 \mathrm{kPa}$, dan berat $>14,5 \mathrm{kPa})$, mendapatkan nilai MPV tertinggi pada kelompok sampel dengan fibrosis berat yaitu 10,0 $(1,4) \mathrm{fL} .{ }^{13}$

Rerata pemeriksaan derajat fibrosis hati menggunakan fibroscan didapatkan hasil sebesar $14,04(9,6) \mathrm{kPa}(\mathrm{F} 4)$, dengan nilai tertinggi $42,5 \mathrm{kPa}$ dan nilai terendah $4,2 \mathrm{kPa}$. Penilaian derajat fibrosis hati menggunakan fibroscan memiliki akurasi tinggi sebagai alat diagnostik non invasif yang hampir sama dengan biopsi hati (gold standard) yaitu dengan menghitung sel fibrogenik secara tidak langsung. Pemeriksaan ini merupakan teknologi pencitraan terbaru yang dikembangkan pada saat ini karena hasil yang cepat, tanpa nyeri, tidak membutuhkan anestesi, dan cukup akurat. ${ }^{16-18}$

Fibrosis hati merupakan respons penyembuhan terhadap cidera berulang, sel parenkim hati, yang akan beregenerasi dan menggantikan sel nekrosis atau apoptosis. Proses ini berkaitan dengan respons inflamasi. Sel inflamasi seperti limfosit dan sel polimorfonuklear akan mengaktifasi HSC untuk mensekresikan kolagen, HSC yang teraktivasi akan mengsekresikan kemokin pro inflamasi. Sel kuffer merupakan makrofag yang berperan utama pada inflamasi hati dengan melepaskan ROS dan sitokin. Hepatosit akan disubstitusi oleh matriks ekstraseluler termasuk kolagen jika cidera hati menetap dan terjadi kegagalan regenerasi hepar. ${ }^{16}$

Uji korelasi didapatkan korelasi positif lemah, tidak terdapat hubungan antara nilai MPV dengan derajat fibrosis hati $(r=0,28)$, tetapi tidak bermakna secara statistik $(p>0,05)$. Penelitian Pan et al (2016) secara retrospektif pada 677 pasien hepatitis B kronik juga mendapatkan korelasi lemah antara nilai MPV dengan derajat fibrosis hati $(r=0,207, p=0,294)$ dan menyimpulkan bahwa tidak terdapat hubungan antara nilai MPV dengan derajat fibrosis hati. ${ }^{12}$ Perbedaan yang bermakna nilai MPV dari empat kelompok derajat fibrosis hati berdasarkan skor metavir pada pasien hepatitis B kronik $(p=0,046)$ didapatkan oleh penelitian Soeliauwan et al., (2018). ${ }^{13}$ Penelitian Rodak et al tahun 2018 juga mendapatkan korelasi positif $(r=0,79$; $\mathrm{p}=0,001$ ) antara nilai MPV dengan fibrosis hati pada 59 orang pasien hepatitis B kronik yang diteliti secara retrospektiif. ${ }^{11}$ Keterbatasan penelitian ini adalah tidak mengelompokkan sampel berdasarkan derajat fibrosis hati, serta rentang nilai maksimum dan minimum yang cukup jauh dengan jumlah sampel yang sedikit sehingga didapatkan korelasi yang lemah antara nilai MPV dan derajat fibrosis hati pada pasien hepatitis $B$ kronik.

Kerusakan hati yang terjadi pada hepatitis B kronik menyebabkan berkurangnya produksi trombopoietin oleh hepatosit seperti yang ditemukan pada penelitian Sembiring tahun 2010. Penelitian tersebut mendapatkan derajat fibrosis hati pada pasien hepatitis B kronik memiliki korelasi negatif dengan kadar trombopoietin. Kadar trombopoietin yang rendah menyebabkan terganggunya proses maturasi trombosit, sehingga peningkatan jumlah trombosit muda yang diproduksi oleh sum-sum tulang pasien hepatitis $\mathrm{B}$ kronik dapat dilihat dari peningkatan nilai MPV. ${ }^{19}$ 


\section{SIMPULAN}

Nilai MPV berkorelasi positif lemah dengan derajat fibrosis hati pada pasien hepatitis B kronik, tetapi bermakna secara statistik $(r=0,28, p=0,18)$.

\section{DAFTAR PUSTAKA}

1. Soemohardjo, Gunawan. Hepatitis B kronik. Dalam: Setiati S, Alwi I, Sudoyo A, Simadibrata M, Setyohadi B, Syam AF, editor (penyunting). Buku ajar ilmu penyakit dalam. Edisi Ke-6. Jilid II. Jakarta Pusat: Interna Publishing; 2014. hlm. $1927-$ 34.

2. Lusida M, Juniastuti, Yano Y. Current hepatitis B virus infection situation in indonesia and its genetic diversity. World Journal Of Gastroenterology. 2016;22(32):7264-70.

3. Jefferies M, Rauff B, Rashid H, Lam T, Rafiq S. Update on global epidemiology of viral hepatitis and preventive strategies. World Journal Of Clinical Case. 2018;6(13):589-99.

4. Muljono D. Epidemiology of hepatitis B and C in Republic of Indonesia. Euroasian Journal of Hepato-Gastroenterology. 2017;7(1):55-9.

5. Wahyuni R. Analisis derajat fibrosis hati dengan fibroscan, indeks FIB4, King's Score, dan APRI Score pada penyakit hepatitis kronis. Jurnal Kesehatan Tadulako. 2016;2(2):42-52.

6. Yu J, Lee J. Current rule of transient elestography in the management of chronic hepatitis $B$ patients. Ultrasonography. 2017;36(2):86-94.

7. Kiratli K, Cevik E. Investigation of mean platelet volume, platelet distribution width and erytocyte distribution width in patients with hepatitis B virus infection. Viral Hepatitis Journal. 2017;23(2):60-3.

8. Hu Y, Lou Y, Chen Y, Mao W. Evaluation of mean platelet volume in patients with hepatitis $B$ virus infection. International Journal of Clinical And Experimental Medicine. 2014;7(11):4207-13.

9. Fritsma G. Platelet Production, Structure, and Function, editor (penyunting). Rodak's Hematology clinical principles and applications. Edisi ke-5. United State of America: Alsevier Saunders; 2016. hlm.167-83.

10. Ekiz F, Yuksel O, Kocak E, Yilmaz B, Altinbas A, Coban S, et al. Mean platelet volume as a fibrosis marker in patientswith chronic hepatitis B. Journal of Clinical Laboratory Analysis. 2011;25: 162-5.

11. Rodak A, Kiciak S, Tomasiewicz. Neutrophillymphocyte ratio and mean platelet volume as predictive factors for liver fibrosis and steatosis in patients with chronic hepatitis B. Annals of Agricultural and Environmental Medicine. 2018;25(4):690-2.

12. Pan Y, Muheremu A, Wu X, Liu J. Relationship between platelet parameters and hepatic pathology in patients with chronic hepatitis B infection - a retrospective cohort study of 677 patients. Journal Of International Medical Research. 2016;44(4): 779-86.

13. Soeliauwan S, Muhadi D, Mutmainnah. Platelet indices for predicting liver fibrosis in patients with chronic hepatitis B infection. Indonesian Journal of Clinical Pathology And Medical Laboratory. 2018; 25(1):35-7.

14. Ceylan B, Mete B, Fincanci M, Aslan T, Akkayunlu $\mathrm{Y}$, Ozgunes $\mathrm{N}$ et al. A new model using platelet indices to predict liver fibrosis in patients with chronic hepatitis b infection. Wiener Klinische Wochenschrift The Central European Journal of Medicine. 2013;125:453-60.

15. Erdem MG, Cil EO, Tukek T, Helvaer SA. Evaluation of platelet and mean platelet volume levels in patients with liver cirrhosis. Archives of Clinical and Experimental Medicine. 2018; 3 (1): 18-21.

16. Anom T, Wibawa I. Pendekatan diagnosis dan terapi fibrosis hati. Jurnal Penyakit Dalam. 2010;11(1):57-67.

17. Baranova A, Lal P, Birerdinc A, Younossi Z. Noninvasive markers for hepatic fibrosis. BioMed Central Gastroenterology. 2011;91:1-15.

18. Jones F, Sembiring J, Lukman HZ. Akurasi diagnostik fibrosis hati berdasarkan rasio red cell distribution width (RDW) dan jumlah trombosit dibanding dengan fibroscan pada penderita hepatitis B kronik. Global Medical And Health Communication. 2016;4(2):104-9.

19. Sembiring J. Correlation between thrombopoietin serum level and liver fibrosis in chronic hepatitis 
patients. Departement of Internal Medicine Faculty of Medicine University of North Sumatera/ Adam Malik
Hospital, Medan. Indon J Gastroenterology and Hepatology Digestive Endoscopy. 2010;11(3):135-42. 